\section{(6) OPEN ACCESS}

\title{
Mexico's epidemic of violence and its public health significance on average length of life
}

\author{
Vladimir Canudas-Romo, ${ }^{1,2,3}$ José Manuel Aburto, ${ }^{1,3}$ Victor Manuel García-Guerrero, ${ }^{4}$ \\ Hiram Beltrán-Sánchez ${ }^{5}$
}

- Additional material is published online only. To view please visit the journal online (http://dx.doi.org/10.1136/jech2015-207015)

${ }^{1}$ Max-Planck Odense Center on the Biodemography of Aging, University of Southern Denmark, Odense C, Denmark ${ }^{2}$ Department of Population, Family and Reproductive Health, Johns Hopkins Bloomberg School of Public Health, Baltimore, Maryland USA

${ }^{3}$ Max Planck Institute for Demographic Research, Rostock, Germany

${ }^{4}$ Centro de Estudios Demográficos, Urbanos y Ambientales, El Colegio de Mexico A.C. México City, México

${ }^{5}$ Department of Community Health Sciences at the Fielding School of Public Health and

California Center for

Population Research, Center for Health Sciences, Los Angeles, California, USA

\section{Correspondence to} Dr Vladimir Canudas-Romo, Max-Planck Odense Center for the Biodemography of Aging, University of Southern Denmark, J.B. Winsløws Vej 9 , 5000 Odense C, Denmark; vcanudas@health.sdu.dk

Received 26 November 2015 Revised 30 May 2016 Accepted 4 July 2016 Published Online First 23 July 2016

\section{ABSTRACT \\ Objectives A disproportionate number of homicides} have caused Mexican life expectancy to stagnate during the new millennium. No efforts currently exist to quantify the harm of violent acts on the lives of the general population. We quantified the impact of perceived vulnerability on life expectancy.

Methods Three Mexican national surveys on perceptions of public safety, life tables, and crime and vital statistics (2000-2014) were used. Prevalence rates of vulnerability/safety by age and sex were obtained from surveys at 2 different levels: federal state and home. The Sullivan method was used to estimate life expectancy lived with and without vulnerability for Mexican women and men.

Results Overall life expectancy at age 20 stagnated between 2005 and 2014 for females and males; yet, there was an increase of $40 \%$ and $70 \%$ in average number of years lived with vulnerability at the state and home levels, respectively. In 2014, female life expectancy at age 20 was 59.5 years $(95 \% \mathrm{Cl} 59.0$ to 60.1$) ; 71 \%$ of these years ( 42.3 years, 41.6 to 43.0 ) were spent with perceived vulnerability of violence taking place in the state and $26 \%$ at the home ( 15.3 years, 15 to 15.8). For males, life expectancy at age 20 was 54.5 years $(53.7$ to 55.1$) ; 64 \%$ of these years (34.6 years, 34.0 to 35.4 ) were lived with perceived vulnerability of violence at the state and $20 \%$ at the home (11.1 years, 10.8 to 11.5 ).

Conclusions The number of years lived with perceived vulnerability among Mexicans has increased by 30.5 million person-years over the last 10 years. If perceived vulnerability remains at its 2014 level, the average Mexican adults would be expected to live a large fraction of his/her life with perceived vulnerability of violence. Acts of violence continue to rise in the country and they should be addressed as a major public health issue before they become endemic.

\section{INTRODUCTION}

Intentional homicides exist in every country. Central America, including Mexico, has the highest homicide rates in the world. ${ }^{1}$ The increase of homicide rates in Mexico during 2007-2014 has had a dramatic impact on the health status of the population, ${ }^{2}$ for example, leading to a stagnation of the overall longevity. ${ }^{3} 4$

The homicide rate is a measure of the level of security and public exposure to violence. ${ }^{1}$ Loss of human lives implies bereaved relatives and friends, but the effects of homicide are not limited to this. ${ }^{5}$ Indirectly, the high levels of homicide rates have been related to worse cognitive performance of children exposed to this crime, ${ }^{6}$ increased anxiety and depression levels, ${ }^{7}$ and a decline in national economic growth rate. ${ }^{8}$

Inflicted mortality is only one expression of violence; the number of people affected by adverse health and socioeconomic consequences from any type of violence exceeds the number of victims of homicides alone. ${ }^{9}$ Violence permeates in the population and creates numerous health problems: somatic, psychological and behavioural. ${ }^{9} 10$ Invisible as some of these problems might be, the continuous exposure to violence affecting individuals and/or their surroundings takes a toll on people's psychological well-being. Thus, the fear and vulnerability prevalent in the population is traceable and as such, the health consequences of violence are measurable.

Efforts to quantify the impact of violence on health, ${ }^{11}$ life spans $^{12}$ and the monetary costs related to actual and potential victims ${ }^{13}$ have revealed the price tag of violence. Despite the rising violence that Central American populations are exposed to and its burden on society, ${ }^{14}$ few efforts have attempted to unravel the implications for the health and well-being of populations. The aim of this study is to assess the impact of violence on well-being in the Mexican population by estimating the average number of years spent vulnerable of becoming victims of violence.

\section{DATA}

\section{Ethics statement}

This study involved secondary data analysis of public sources, which did not have any individual identifiers. As such, ethical approval for human subject research from the Institutional Review Board of the respective institutions was exempted.

Five data sources were used in the analysis: the 2005, 2010 and 2014 Mexican national surveys of perception of public safety 'Encuesta Nacional sobre Inseguridad' (ENSI-2005 and ENSI-2010), ${ }^{15}$ and 'Encuesta Nacional de Victimización y Percepción sobre seguridad pública' (ENVIPE-2014), ${ }^{16}$ life tables for the Mexican population for the same years, ${ }^{17}{ }^{18}$ national homicide counts ${ }^{19}$ and official reported crime rates for kidnapping and extortion. ${ }^{20}$ These surveys of the perception of public safety, ENSI and ENVIPE, are based on a probabilistic, multistage, stratified cluster sample design specifically created to assess characteristics of acts of violence, with a particular focus on the victim, victim's family and the context in which the event occurred. $^{15} 16$ The sample frame for ENSI-2005, ENSI-2010 and ENVIPE-2014 included 66000 , 73370 and 95517 households, respectively, with representation at the national, state and 
metropolitan level. From each household, an individual aged 18 or older was randomly selected and interviewed to collect information on the household regarding sociodemographic factors, perception of public safety and the performance of the judicial system, as well as listing any violent act that a household member or respondent had been victims of. For example, the list of violent acts included in the ENVIPE-2014 survey was: theft, injuries, damage to property, threats, fraud, homicide, rape and other sexual offences, extortion and kidnapping. From these surveys, we selected people aged 20 or older representing over 93\% of the survey respondents in ENSI-2005, ENSI-2010 and ENVIPE-2014.

Information on homicide counts (ICD-10 code: X85-Y09) was available by sex and single years of age for each year from 2000 to $2014 .{ }^{19}$ Reported numbers were age-standardised using the age-specific population counts for Mexico in 2014. Rates of kidnapping (the act of abducting someone and holding them captive) and extortion (obtaining something, especially money, through force or threats) were available on an annual basis without disaggregation by age or sex. ${ }^{20}$ Period life tables, elaborated by the Mexican Demographic Society (SOMEDE) for the Mexican population for 2005 and 2010, were used ${ }^{17}$ together with life tables forecasted for 2014 and $2020 .^{18}$ The median projection of the latter life tables is comparable with official projected life tables with the advantage that they are stochastic, which means that they take into account the uncertainty that surrounds mortality. Such uncertainty was used here for calculating the corresponding CIs. These mortality data are available by sex and single-age, with an open age-group 107 and older.

\section{Measures}

Vulnerability was measured by respondents' perception of crime in 2005, 2010 and 2014 at two levels (federal state, hereafter referred to as state, and at home) based on answers to the question 'In terms of crime, how do you consider living in your [state/ home] is?' with two response options: 'vulnerable' and 'safe'. The prevalence of vulnerability was estimated at every age for the two levels: state, $\pi_{\mathrm{x}}$ (state) and home, $\pi_{\mathrm{x}}$ (home); where $\pi_{\mathrm{x}}$ denotes the prevalence of vulnerability in the population at age $\mathrm{x}$. Local polynomial regressions were applied to the prevalence rates to smooth out the data and avoid fluctuations from age to age, while maintaining only minor deviations from the raw data (see online supplementary appendix). This process also allowed us to carry out sensitivity analysis to confirm the robustness of our results (see online supplementary appendix).

\section{METHODS}

The Sullivan method was used to calculate the person-years and the remaining years of life spent with and without vulnerability at different ages. ${ }^{21}$ Let the number of years lived by the population at age $\mathrm{x}$ be represented by the life table measure of personyears $\left(\mathrm{L}_{\mathrm{x}}\right)$. The product of the person-years and the prevalence rate of vulnerability allow separating $\mathrm{L}_{\mathrm{x}}$ into person-years lived with and without vulnerability, as $\mathrm{L}_{\mathrm{x}} \times \pi_{\mathrm{x}}$ and $\mathrm{L}_{\mathrm{x}} \times\left(1-\pi_{\mathrm{x}}\right)$, respectively. From these two sets of person-years, standard life table calculations are performed to obtain life expectancies lived with and without vulnerability. ${ }^{22}$ Thus, the average number of years lived at age $\mathrm{x}, \mathrm{e}_{\mathrm{x}}$, is decomposed as the number of years lived with vulnerability and years without vulnerability: $\mathrm{e}_{\mathrm{x}}=\mathrm{e}_{\mathrm{x}}$ (vulnerability) $+\mathrm{e}_{\mathrm{x}}$ (without vulnerability). More details on the Sullivan method are available elsewhere. ${ }^{21}$ Life expectancies with and without vulnerability were calculated for locations: state and home.
The 95\% CIs of life expectancies with vulnerability were derived from the 95\% CI from the life tables and the SEs from the prevalence of vulnerability. ${ }^{18}{ }^{21}$ Calculations were done by single years from ages 20 to 95, with an open age-group 96 and older, and separately by sex. We used a normal z-test for the statistical significance of differences between the prevalence of vulnerability by age for males and females. Finally, we used prevalence rates in 2005-2014 to project the prevalence for year 2020 using three approaches: constant, linear and quadratic. All the analyses were carried out using the $\mathrm{R}$ software (http://www.r-project.org/).

\section{Limitations}

Limitations of our study should be mentioned. First, our initial goal was to measure the number of years that the Mexican population spends in fear of acts of violence. However, the survey used did not explicitly ask for the level of fear that people were in. Instead, we used the question on vulnerability/ safety as a proxy to the former concept. Second, our results include only violent acts directly having an impact on individuals as assessed by the ENSI and ENVIPE surveys. ${ }^{15} 16$ Although our selected surveys only include certain types of crimes, our results represent the perception of vulnerability and security reflecting the overall experience of the respondent. Third, the Sullivan method assumes that the same mortality pattern follows irrespective of the living status (ie, with and without vulnerability). ${ }^{21}$ Although stress caused by violent acts might raise the risk of death of those feeling vulnerable, ${ }^{23}$ we have no follow-up longitudinal studies to disentangle differential mortality related to vulnerability in the Mexican population. This illustrates the urgent need to collect longitudinal data that inform more precisely on the impact of the violence that the Mexican population has been exposed to in the first years of the 21 st century. $^{2-4}$

\section{RESULTS}

Time-trends of kidnapping, extortion and homicides between 2000 and 2014 in Mexico are shown in figure 1. The kidnapping rate more than doubled over the period, from 0.6 (95\% CI 0.54 to 0.64$)$ to a peak of 1.4 (1.36 to 1.50$)$ per 100000 , and extortions had a sixfold increase from 1.2 (1.09 to 1.23) to 6.9

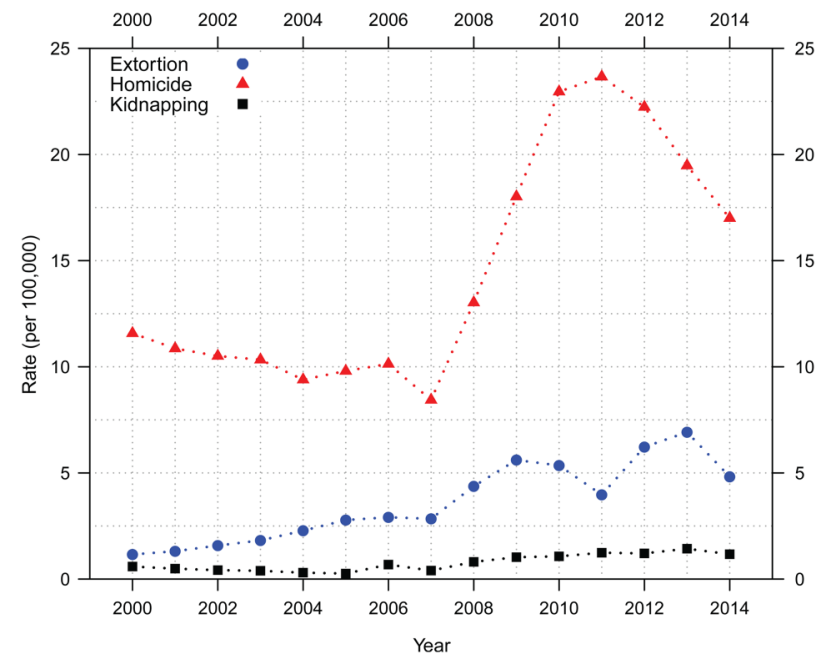

Figure 1 Rates of extortion, homicide and kidnapping for the Mexican population from 2000 to 2014. Source: data from INEGI ${ }^{19}$ and SEGOB. ${ }^{20}$ 
(6.77 to 7.07$)$ per 100000 . Homicide rates declined from 2000 to 2007 , from 11.6 (11.37 to 11.79 ) to 8.4 (8.26 to 8.61 ) per 100000 , had a sharp increase between 2007 and 2011 with a peak of 23.7 (23.38 to 23.94) deaths per 100000 in 2011 (a total of 27213 deaths) and declined thereafter. Still, homicide rates in 2014 remained at more than double the level of 2007. These high homicide rates, along with the high rates in other types of violence, have had a toll on the population's well-being as seen in the prevalence of vulnerability.

Table 1 includes the prevalence of self-reported vulnerability for 2005, 2010 and 2014 for Mexican females and males at the state and home levels. Importantly, 2005 shows the prevalence for the time before the increase in violence, particularly homicide, whereas the other years capture the period of increase in violence (see figure 1). Vulnerability at the state level is higher than at home, at every time, age and for both sexes. Age patterns of the prevalence of vulnerability show a decline with age for 2005, whereas 2010 and 2014 are characterised by beginning with a slight increase and then a decline with age. In 2005, the prevalence peaks at ages 20-49, whereas in 2010 and 2014 it has shifted to older ages 40-59. In 2005, 2010 and 2014, females' highest concentration of vulnerability at the state level increases from $56 \%$ to $72 \%$ and goes further up to $74 \%$, and vulnerability at the home level begins at $17 \%$, rising to $23 \%$ and $30 \%$, for those same years. Males reported significantly less vulnerability compared to females at ages 20-69 at the state and home levels.

Life table survival functions for Mexican females at ages 20 and older in 2005 and 2014 are practically identical, reflecting stagnation in overall survival in the decade (figure 2). At each age, the number of person-years is separated into those lived with and without vulnerability with a further disaggregation of vulnerability at the state (figure 2, top row) and home (bottom row) levels. The average number of person-years with vulnerability at the state level is more than three times higher than those at home, but the upturn in vulnerability between 2005 and 2014 is greater at home, and the gap between vulnerability at the state and home levels falls. Males show similar results although with fewer person-years with vulnerability (see online supplementary appendix).

Life expectancies with and without vulnerability are summarised in table 2. Between 2005 and 2014, life expectancy at age 20 increased by a third of a year for females (2005: 59.2 years, 95\% CI 59.2 to 59.3 ; 2014: 59.5 years, 59.0 to 60.1) and stagnated for males (2005 and 2014 at 54.4 years, 53.7 to 55.1 ). On the contrary, life expectancy with vulnerability increased its share over time.

While females have greater life expectancy than males at every age, they spend most of the extra years with perceived vulnerability. Importantly, the percentage difference in years spent with vulnerability between the sexes is highest at younger adult ages. In 2005, for example, females aged 20 spent about 51\% of their remaining life with vulnerability at the state level (30.1 years, 95\% CI 29.7 to 30.5), while the corresponding value for males is about 46\% (24.9 years, 24.5 to 25.4). By 2014, vulnerability has reached alarming levels: females aged 20 spent about $71 \%$ of their remaining life with vulnerability at the state level (42.3 years, 41.6 to 43.0 ), whereas the corresponding value for males is about $64 \%$ (34.6 years, 34.0 to 35.4 ).

A large increase of life span spent in years of vulnerability between 2005 and 2014 is seen at state and home levels. For example, at age 20 , female life expectancy with vulnerability at the home level increases linearly from $14 \%$ in 2005 , to $20 \%$ in 2010 and $26 \%$ in 2014 (2005: 8.4 years, 95\% CI 8.2 to 8.7; 2010: 11.7 years, 11.5 to 12.1 ; 2014: 15.3 years, 15.0 to 15.8 ). The corresponding proportions for males are $12 \%, 16 \%$ and 20\%, for 2005, 2010 and 2014, respectively (2005: 6.5 years, $95 \%$ CI 6.3 to $6.9 ; 2010: 8.6$ years, 8.4 to $8.9 ; 2014$ :

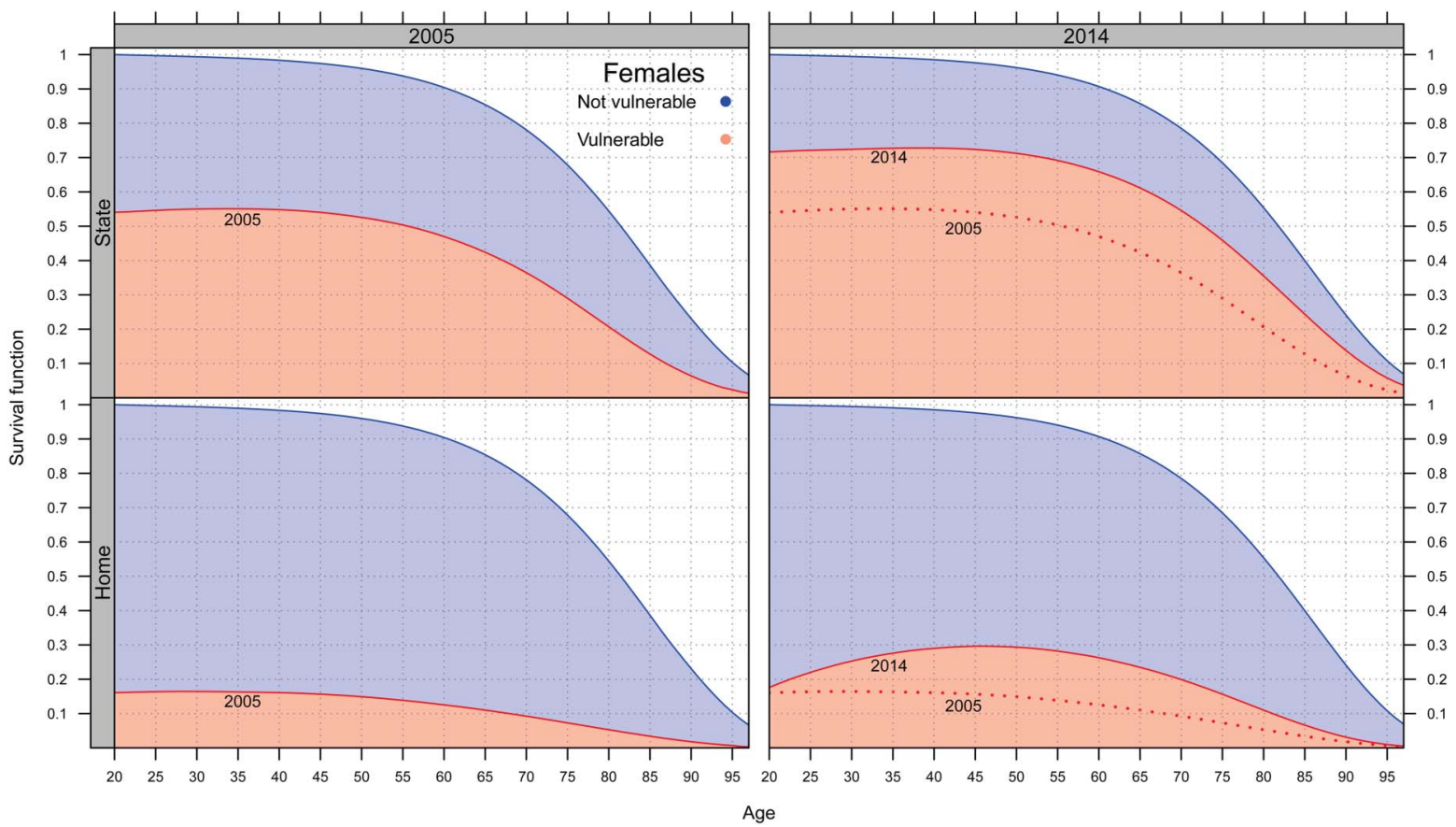

Figure 2 Person-years lived with and without vulnerability at the state (top row) and home (bottom row) levels for Mexican females aged 20 and older in 2005 and 2014. Source: Authors' calculations, data from the ENSI-2005, ENSI-2010 ${ }^{15}$ and ENVIPE-2014 ${ }^{16}$ surveys, and period life tables. $^{17} 18$ 
11.1 years, 10.8 to 11.5$)$. Life expectancies with vulnerability at other ages also show similar expanding share in Mexican lives over the 2005-2014 decade.

The actual number of people aged 20 and above feeling vulnerable to violence can be calculated as the product of the estimated years spent with vulnerability and the population size at this age. For 2005, 2010 and 2014, the number of Mexican person-years lived with vulnerability is 53.1, 77.3 and 83.6 million, respectively. This is equivalent to an increase in the number of years with vulnerability of 30.5 million, resulting from the increase in violence in the country between 2005 and 2014. continues to 2020, female life expectancy at age 20 is estimated to be 60.11 years (CI 61.11 to 59.11), of which $71 \%$ (62\% to $87 \%$ ) could be spent with vulnerability at the state and 33\% (26\% to $37 \%$ ) at the home level. For males, the corresponding life expectancy is estimated to be 54.96 years (55.96 to 53.96), with $64 \%$ (43\% to $79 \%$ ) with vulnerability at the state and $26 \%$ (21\% to $30 \%)$ at the home level. Thus, for females and males, while vulnerability at the state level could stay in the same range, safety perception at home might experience a substantial increase compared with values for 2014 .

\section{DISCUSSION}

This is the first study to unravel implications of violence, other than homicides, on average length of life in the Mexican population. We dissect average years of life into years living with and without vulnerability. Based on the perception of vulnerability in 2005, 2010 and 2014, Mexicans' feelings of safety have reached remarkable low levels and rather than improving they are worsening. While in 2005 Mexican adults spent less than half of their life spans with perceived vulnerability of violence, they now spend two-thirds of their life spans with vulnerability. shadow of vulnerability is also evident there. Mexican females enjoy greater life expectancies than males, but much of that extra life span is marred by the perception of vulnerability.

Our results show that the proportion of people living with vulnerability increases in relation to the distance from their home. It can be speculated that this incremental perceived vulnerability corresponds to people's interpretation of the mass media description of distant events at the state and national level (eg, http://www.economist.com/blogs/graphicdetail/2012/ $11 /$ mexican-drug-war), their visual inspection of their surroundings including the perception of corruption and impunity of public institutions, ${ }^{24}$ and their own experience (home). This concentric identification of individuals and the negative effect of violence in the media is known as the 'third-person effect' favouring the in-group. ${ }^{25}$ However, $7 \%$ of the Mexicans interviewed in 2014 responded in a reverse manner perceiving higher security outside their home. ${ }^{16}$ This might be related to family or partner violence ${ }^{926}$ not fully explored in the survey.

Some evidence indicates that Mexicans have learned to cope with violent shocks. ${ }^{27}$ However, our results indicate that violence has left an imprint on people's perceptions of their surroundings. Among those interviewed in the ENVIPE-2014 survey, ${ }^{16}$ a third $(33 \%)$ reported the experience of a violent event in years previous to 2013 as opposed to $14 \%$ in 2013. Nonetheless, victims of previous years reported the same levels of vulnerability as victims in 2013. The sequels of violent events can last for a long time and their impact can be seen in somatic and mental health. ${ }^{9} 10$
If the increasing tendency in the perception of vulnerability Home is defined as the less vulnerable shelter, although the

The perception of vulnerability of the Mexican population has increased in parallel with the greater number of homicides in the country. The lowest number of homicides in the decade was reported in 2007 (see figure 1), and surveys on security indicated that $29 \%$ of the population reported living with vulnerability the previous year. ${ }^{28}$ By 2011, however, the number of homicides had increased by threefold, whereas $71 \%$ of respondents reported living with vulnerability. ${ }^{15}$ These high levels of homicides ${ }^{19}$ and perceived vulnerability have remained high until the present (see table 1). Furthermore, other types of violence, as kidnapping and extortion reported in figure 1, obtained from official crime reports by victims ${ }^{20}$ also indicate an important toll of violence on the Mexican population. Although these numbers show a dismaying picture, they only represent an underestimate of the actual violence that the Mexican population is exposed to. ${ }^{29}$

Among the ENVIPE-2014 interviewees, crimes in 2013 and those years preceding 2013 were evenly distributed between female and male victims at $13 \%$ and $15 \%$, and $32 \%$ and $35 \%$, respectively. ${ }^{16}$ Nevertheless, our results show that the share of people living with vulnerability is greater for women than for men, particularly for younger adults. Furthermore, there is a larger sex disparity at the state than at the home level. This difference in perception might be related to differential processing of information regarding perceived threats between men and women. Evidence from clinical psychology indicates that

Table 1 Prevalence of self-reported vulnerability among Mexicans (\%), 2005, 2010 and 2014

\begin{tabular}{|c|c|c|c|c|c|c|}
\hline \multirow[b]{2}{*}{ Age-group } & \multicolumn{3}{|l|}{ State } & \multicolumn{3}{|l|}{ Home } \\
\hline & Female & Male & p Value* & Female & Male & p Value* \\
\hline \multicolumn{7}{|l|}{2005} \\
\hline $20-29$ & 54 & 49 & 0.000 & 16 & 13 & 0.000 \\
\hline $30-39$ & 56 & 51 & 0.000 & 17 & 13 & 0.000 \\
\hline $40-49$ & 56 & 49 & 0.000 & 16 & 13 & 0.000 \\
\hline $50-59$ & 54 & 46 & 0.000 & 15 & 12 & 0.000 \\
\hline $60-69$ & 51 & 43 & 0.000 & 14 & 9 & 0.000 \\
\hline $70-79$ & 44 & 41 & 0.125 & 10 & 10 & 0.723 \\
\hline $80-89$ & 37 & 35 & 0.478 & 9 & 7 & 0.387 \\
\hline $90+$ & 27 & 40 & 0.160 & 11 & 12 & 0.876 \\
\hline \multicolumn{7}{|l|}{2010} \\
\hline $20-29$ & 67 & 63 & 0.000 & 17 & 13 & 0.000 \\
\hline $30-39$ & 71 & 65 & 0.000 & 21 & 17 & 0.000 \\
\hline $40-49$ & 72 & 67 & 0.000 & 23 & 18 & 0.000 \\
\hline $50-59$ & 71 & 67 & 0.000 & 23 & 19 & 0.000 \\
\hline $60-69$ & 67 & 65 & 0.085 & 21 & 19 & 0.025 \\
\hline $70-79$ & 63 & 59 & 0.016 & 17 & 15 & 0.115 \\
\hline $80-89$ & 58 & 54 & 0.200 & 14 & 10 & 0.036 \\
\hline $90+$ & 54 & 47 & 0.357 & 19 & 15 & 0.495 \\
\hline \multicolumn{7}{|l|}{2014} \\
\hline $20-29$ & 72 & 63 & 0.000 & 22 & 16 & 0.000 \\
\hline $30-39$ & 74 & 63 & 0.000 & 28 & 21 & 0.000 \\
\hline $40-49$ & 74 & 65 & 0.000 & 30 & 24 & 0.000 \\
\hline 50-59 & 74 & 67 & 0.000 & 30 & 25 & 0.000 \\
\hline $60-69$ & 72 & 66 & 0.000 & 27 & 24 & 0.007 \\
\hline $70-79$ & 68 & 63 & 0.001 & 23 & 18 & 0.000 \\
\hline $80-89$ & 62 & 59 & 0.166 & 17 & 17 & 0.871 \\
\hline $90+$ & 63 & 55 & 0.250 & 13 & 14 & 0.715 \\
\hline
\end{tabular}


Table 2 Mexican life expectancy with and without vulnerability at selected ages, 2005, 2010 and 2014

\begin{tabular}{|c|c|c|c|c|c|c|}
\hline & \multirow[b]{2}{*}{ Age } & \multirow[b]{2}{*}{ Life expectancy $(95 \% \mathrm{Cl})$} & \multicolumn{2}{|c|}{ Vulnerable expectancy (95\% Cl) } & \multicolumn{2}{|c|}{$\begin{array}{l}\text { Vulnerable expectancy } \\
\text { (\% of total) }\end{array}$} \\
\hline & & & State & Home & State & Home \\
\hline \multicolumn{7}{|l|}{2005} \\
\hline Females & $\begin{array}{l}20 \\
40 \\
60 \\
80\end{array}$ & $\begin{array}{c}59.2(59.2 \text { to } 59.3) \\
40.0(40.0 \text { to } 40.1) \\
22.4(22.4 \text { to } 22.5) \\
9.2(9.2 \text { to } 9.3)\end{array}$ & $\begin{array}{c}30.1(29.7 \text { to } 30.5) \\
19.4(19.1 \text { to } 19.9) \\
9.6(9.3 \text { to } 10.0) \\
2.9(2.5 \text { to } 3.4)\end{array}$ & $\begin{array}{l}8.4(8.2 \text { to } 8.7) \\
5.2(5.1 \text { to } 5.6) \\
2.4(2.3 \text { to } 2.7) \\
0.7(0.5 \text { to } 1.0)\end{array}$ & $\begin{array}{l}51 \\
49 \\
43 \\
31\end{array}$ & $\begin{array}{l}14 \\
13 \\
11 \\
8\end{array}$ \\
\hline Males & $\begin{array}{l}20 \\
40 \\
60 \\
80\end{array}$ & $\begin{array}{c}54.4(54.4 \text { to } 54.5) \\
36.5(36.5 \text { to } 36.6) \\
20.2(20.2 \text { to } 20.3) \\
8.6(8.6 \text { to } 8.7)\end{array}$ & $\begin{array}{c}24.9(24.5 \text { to } 25.4) \\
15.9(15.6 \text { to } 16.4) \\
8.0(7.7 \text { to } 8.4) \\
2.6(2.2 \text { to } 3.0)\end{array}$ & $\begin{array}{l}6.5 \text { (6.3 to } 6.9) \\
4.1 \text { (3.9 to } 4.4) \\
2.1(1.9 \text { to } 2.4) \\
1.0(0.7 \text { to } 1.4)\end{array}$ & $\begin{array}{l}46 \\
44 \\
40 \\
30\end{array}$ & $\begin{array}{l}12 \\
11 \\
11 \\
12\end{array}$ \\
\hline \multicolumn{7}{|l|}{2010} \\
\hline Females & $\begin{array}{l}20 \\
40 \\
60 \\
80\end{array}$ & $\begin{array}{c}59.3(59.3 \text { to } 59.4) \\
40.1(40.1 \text { to } 40.2) \\
22.5(22.5 \text { to } 22.5) \\
9.3(9.3 \text { to } 9.4)\end{array}$ & $\begin{array}{c}39.8(39.4 \text { to } 40.2) \\
26.6(26.3 \text { to } 27.0) \\
14.0(13.7 \text { to } 14.4) \\
5.1(4.8 \text { to } 5.5)\end{array}$ & $\begin{array}{l}11.7(11.5 \text { to } 12.1) \\
8.1(7.9 \text { to } 8.4) \\
4.1(3.9 \text { to } 4.4) \\
1.4(1.2 \text { to } 1.7)\end{array}$ & $\begin{array}{l}67 \\
66 \\
62 \\
55\end{array}$ & $\begin{array}{l}20 \\
20 \\
18 \\
16\end{array}$ \\
\hline Males & $\begin{array}{l}20 \\
40 \\
60 \\
80\end{array}$ & $\begin{array}{c}53.8(53.8 \text { to } 53.9) \\
36.4(36.4 \text { to } 36.5) \\
20.2(20.2 \text { to } 20.3) \\
8.5(8.5 \text { to } 8.6)\end{array}$ & $\begin{array}{c}34.0(33.6 \text { to } 34.4) \\
22.8(22.5 \text { to } 23.3) \\
12.0(11.7 \text { to } 12.4) \\
4.4(4.1 \text { to } 4.8)\end{array}$ & $\begin{array}{l}8.6(8.4 \text { to } 8.9) \\
6.1(5.9 \text { to } 6.4) \\
3.1(2.9 \text { to } 3.3) \\
1.0(0.8 \text { to } 1.3)\end{array}$ & $\begin{array}{l}63 \\
63 \\
59 \\
52\end{array}$ & $\begin{array}{l}16 \\
17 \\
15 \\
12\end{array}$ \\
\hline \multicolumn{7}{|l|}{2014} \\
\hline Females & $\begin{array}{l}20 \\
40 \\
60 \\
80\end{array}$ & $\begin{array}{l}59.5(59.0 \text { to } 60.1) \\
40.3(39.8 \text { to } 40.8) \\
22.6(22.3 \text { to } 23.0) \\
9.4(9.3 \text { to } 9.6)\end{array}$ & $\begin{array}{c}42.3(41.6 \text { to } 43.0) \\
28.2(27.7 \text { to } 28.9) \\
15.1(14.7 \text { to } 15.6) \\
5.5(5.2 \text { to } 5.9)\end{array}$ & $\begin{array}{l}15.3(15.0 \text { to } 15.8) \\
10.6(10.3 \text { to } 11.0) \\
5.2(4.9 \text { to } 5.5) \\
1.4(1.2 \text { to } 1.7)\end{array}$ & $\begin{array}{l}71 \\
70 \\
67 \\
59\end{array}$ & $\begin{array}{l}26 \\
26 \\
23 \\
15\end{array}$ \\
\hline Males & $\begin{array}{l}20 \\
40 \\
60 \\
80\end{array}$ & $\begin{array}{c}54.4(53.7 \text { to } 55.1) \\
36.6(36.1 \text { to } 37.1) \\
20.4(20.1 \text { to } 20.7) \\
8.7(8.6 \text { to } 8.9)\end{array}$ & $\begin{array}{c}34.6(34.0 \text { to } 35.4) \\
23.4(22.9 \text { to } 24.1) \\
12.7(12.3 \text { to } 13.2) \\
5.0(4.6 \text { to } 5.4)\end{array}$ & $\begin{array}{l}11.1(10.8 \text { to } 11.5) \\
8.0(7.7 \text { to } 8.4) \\
4.1(3.8 \text { to } 4.4) \\
1.4(1.2 \text { to } 1.7)\end{array}$ & $\begin{array}{l}64 \\
64 \\
63 \\
57\end{array}$ & $\begin{array}{l}20 \\
22 \\
20 \\
16\end{array}$ \\
\hline
\end{tabular}

Authors' calculations, data from the ENSI-2005, ENSI-2010 ${ }^{15}$ and ENVIPE-2014 ${ }^{16}$ surveys, and period life tables. ${ }^{17} 18$

women are more likely than men to report higher levels of anxiety. ${ }^{30}$ Though, greater vulnerability of crime among women does not necessarily translate into a higher risk of being victimised. $^{31}$

In other countries in Central America, for example, Honduras, Belize, El Salvador and Guatemala, as well as in South America, for example, Venezuela, Brazil and Colombia, similar high levels of homicides are reported. In many cases, homicide rates are actually higher than in Mexico. ${ }^{1}$ Furthermore, in the Americas, homicides are frequently linked to other criminal activities, particularly those related to drug cartels and gangs, ${ }^{32}$ and thus other violent acts are also high. The high proportion of years lived with vulnerability presented here for the Mexican population could be expected to be present in these countries too. More research is needed to quantify and understand the toll that violence is having on the wellbeing of the residents of Central and South America. The strong migration flows back and forth from Central to North America, ${ }^{33}$ and their tight links to violent events, ${ }^{34}$ related to gangs $^{32}$ and drug cartels, ${ }^{35}$ make the increasing violence problem in the south a cross-regional concern and therefore a top priority for public health research.

Our results clearly indicate major implications of the upsurge of violence and homicides in Mexico in the past decade with a remarkable impact on the well-being of the Mexican population. Between 2000 and 2014, rates of kidnapping, extortion and homicide increased by twofold, threefold and twofold, respectively, whereas the proportion of people living with vulnerability skyrocketed. There is an urgent need to see this problem as a major public health issue and to address it accordingly. ${ }^{2}$ There should be prevention strategies at the state and home levels as

\section{What is already known on this subject}

Numerous studies have documented an increase in drug-related violence in Mexico after 2007. ${ }^{27} 32$ Research on its causes and consequences point towards drug-related crime. ${ }^{19}$ This is particularly notable in Mexico, which had one of the lowest homicide rates of the Latin American region a decade earlier. ${ }^{2-4}$ Few studies have used the perception of vulnerability to assess the impact of violence on the quality of life for the general population; ${ }^{78}$ furthermore, no article has attempted to calculate the number of years that Mexicans would spend living with vulnerability.

\section{What this study adds}

The alarming proportion of Mexicans' lives spent with perceived vulnerability of violence at the state and at home illustrates the burden violence poses on the psychosocial well-being of the population. The high level of violence in other Latin American countries ${ }^{1}$ leads to assumptions that vulnerability plays a similar role in these countries. Ideally, policymakers should use preventive strategies to address the burden of violence felt in families and on a social level. However, neutralising violence using state force has been shown to be counterproductive in the Mexican context. ${ }^{4}$ 
well as for the entire nation. ${ }^{9}$ Efforts should be implemented as part of the educational and social policies and programmes, and particular efforts should be made to help victims of violence. ${ }^{10}$ Equity in access to health, education, work and economic opportunity as well as interventions to reduce childhood exposure to violence and its devastating consequences, which carry over into later life, are essential to avoid major effects in subsequent generations. ${ }^{9}$ Yet, the Mexican government has been unable so far to guarantee the safety of its population and no major efforts have been made to address the structural roots of the problem.

Twitter Follow Hiram Beltrán-Sánchez at @HBeltranSanchez José Aburto at @jm_aburto and Víctor García-Guerrero at @vicmgg

Acknowledgements The authors thank their supporting institutions, the European Research Council grant 240795 the European Doctoral School of Demography, and $\mathrm{NIH}$ grants R24HD047873, R24HD041022 and P30AG017266. The funding sources had no influence on the study design, data collection, analysis and interpretation of data, or the writing of the article and the decision to submit the article. The authors also express our gratitude to Annette Erlangsen, Roberto Ham and anonymous referees for all their comments and suggestions and the open access sponsor, the University Library of Southern Denmark.

Contributors HB-S, VMG-G, JMA and VC-R designed the conception of the study. JMA and VC-R did the statistical analyses with advice from HB-S and VMG-G, and all authors helped to interpret the results. VC-R wrote the first draft and all other authors reviewed and revised the manuscript. All authors approved of the final version.

Funding The first, second and last authors received salary support from the European Research Council grant 240795, the European Doctoral School of Demography, and NIH grants R24HD047873, R24HD041022 and P30AG017266, respectively.

Competing interests None declared.

Provenance and peer review Not commissioned; externally peer reviewed.

Data sharing statement We used free available data and proper citation is included in the reference list for any researcher to have access to it.

Open Access This is an Open Access article distributed in accordance with the Creative Commons Attribution Non Commercial (CC BY-NC 4.0) license, which permits others to distribute, remix, adapt, build upon this work non-commercially, and license their derivative works on different terms, provided the original work is properly cited and the use is non-commercial. See: http://creativecommons.org/ licenses/by-nc/4.0/

\section{REFERENCES}

1 United Nations Office on Drugs and Crime (UNODC). Global Study on Homicide 2013. United Nations Publication, 2013. Sales No. 14.IV.1.

2 Gamlin J. Violence and homicide in Mexico: a global health issue. Lancet 2015:385:605-6.

3 Canudas-Romo V, García-Guerrero VM, Echarri-Cánovas CJ. The stagnation of the Mexican male life expectancy in the first decade of the 21st century: the impact of homicides and diabetes mellitus. JECH 2014;68:1-7.

4 Aburto JM, Beltrán-Sánchez H, García-Guerrero VM, et al. Homicides in Mexico reversed life expectancy gains for men and slowed them for women, 2000-10. Health Aff (Millwood) 2016;35:88-95.

5 Aldrich $\mathrm{H}$, Kallivayalil $\mathrm{D}$. The impact of homicide on survivors and clinicians. J Loss Trauma 2013;18:362-77.

6 Sharkey P. The acute effect of local homicides on children's cognitive performance. Proc Natl Acad Sci 2010;107:11733-8.

7 Michaelsen MM. Mental health and labour supply-evidence from México's ongoing violent conflicts. Ruhr Economic Paper 2012:378.

8 Detotto C, Otranto E. Does crime affect economic growth? Kyklos 2010;63:330-45.

9 Krug EG, Mercy JA, Dahlberg LL, et al. The world report on violence and health. Lancet 2002;360:1083-8.

10 Prince M, Patel V, Saxena S, et al. No health without mental health. Lancet 2007:370:859-77.

11 Dolan $\mathrm{P}$, Loomes $\mathrm{G}$, Peasgood T, et al. Estimating the intangible victim costs of crime. Br J Criminol 2005;45:958-76.
12 Redelings M, Lieb L, Sorvillo F. Years off your life? The effects of homicide on life expectancy by neighborhood and race/ethnicity in Los Angeles County. J Urban Health 2010;87:670-6.

13 Dolan P, Peasgood T. Estimating the economic and social costs of the fear of crime. Br J Criminol 2007:47:121-32.

14 Naghavi M, Wang H, Rafael L, et al. Global, regional, and national age-sex specific all-cause and cause-specific mortality for 240 causes of death, 1990-2013: a systematic analysis for the global burden of disease study 2013. Lancet 2015;385:117-71.

15 Mexican National Institute of Statistics and Geography (INEGI). Mexican National Survey of Public Safety [In spanish: Encuesta Nacional de Inseguridad] (ENSI). http:// www.inegi.org.mx/est/contenidos/proyectos/encuestas/hogares/especiales/ensi/

16 Mexican National Institute of Statistics and Geography (INEGI). Mexican National Survey of Victimization and Perception of Public Safety [In spanish: Encuesta Nacional de Victimización y Percepción sobre Seguridad Pública] (ENVIPE). http:/l www.inegi.org.mx/est/contenidos/proyectos/encuestas/hogares/regulares/envipe/

17 SOMEDE, Mexican Demographic Society. Demographic estimates for Mexico and its states, 1990-2010. [In spanish: Estimaciones demográficas de México y entidades federativas, 1990-2010]. México: National Population Council and SOMEDE, 2011.

18 García Guerrero VM. Projections and Population Policies in Mexico. [In spanish: Proyecciones y políticas de población en México]. México: El Colegio de México, 2014.

19 Mexican National Institute of Statistics and Geography (INEGI). Administrative registers, deaths by homicide. http://www.inegi.org.mx/est/contenidos/proyectos/ registros/vitales/mortalidad/default.aspx (accessed Jan 2015).

20 Mexican National Security System (SEGOB). Crime incidence. http://www. secretariadoejecutivo.gob.mx/index.php (accessed Mar 2015).

21 Sullivan DF. A single index of mortality and morbidity. HSMHA Health Rep 1971;86:347-54

22 Preston S, Heuveline P, Guillot M. Demography. Measuring and modeling population processes. Malden (MA): Blackwell Press, 2001.

23 Shenhar-Tsarfaty S, Yayon N, Waiskopf N, et al. Fear and C-reactive protein cosynergize annual pulse increases in healthy adults. Proc Natl Acad Sci USA 2015;112:E467-71.

24 Alvarado A, Serrano M. Volume XV. National Security and Interior Security [In Spanish: Volúmen XV. Seguridad Pública y Seguridad Interior] in Ordorica M. and Prud'homme JF. (coords.) The Big Problems of Mexico. [In Spanish: Los grandes problemas de México]. México: El Colegio de México, 2010.

25 Scharrer E. Third-person perception and television violence: the role of out-group stereotyping in perceptions of susceptibility to effects. Commun Res 2002;29:681-704.

26 Campbell JC. Health consequences of intimate partner violence. Lancet 2002;359:1331-6.

27 Villarreal A. Fear and spectacular drug violence in monterrey. In: Auyero J, Bourgois $\mathrm{P}$, Scheper-Hughes N, eds. Violence at the urban margins. Oxford University Press, 2015;135-61.

28 Vilalta-Perdomo CJ. The fear to crime in Mexico: logic, base and first public policies [In spanish: El miedo al crimen en México: Estructura lógica, bases empíricas y recomendaciones iniciales de política pública]. Gest Polít Pública 2010;19:3-36

29 Jiménez Ornelas R. The challenges of public safety in Mexico. Negative perception of the public safety: Mexico city and Mexico. [In spanish: Los desafíos de la seguridad pública en México. percepción negativa de la seguridad pública: ciudad de México y república mexicana]. In: Jiménez Ornelas $R$, Silva Forné $C$, eds. Perception of the performance of the safety and justice institutions [In spanish: Percepción del desempeño de las instituciones de seguridad y justicia]. Legal Research Institute, UNAM, 2015:149-64.

30 McLean $C P$, Anderson ER. Brave men and timid women? A review of the gender differences in fear and anxiety. Clin Psychol Rev 2009;29:496-505.

31 Fetchenhauer D, Buunk BP. How to explain gender differences in fear of crime: towards an evolutionary approach. Sex Evol Gender 2005; 7:95-113.

32 Arana A. How the street gangs took Central America. Foreign Affairs 2005;84:98-110

33 Massey DS, Riosmena F. Undocumented migration from Latin America in an era of rising U.S. enforcement. Ann Am Acad Pol Soc Sci 2010;630: 294-321.

34 Imbusch P, Misse M, Carrión F. Violence research in Latin America and the Caribbean: a literature review. Int I Conf Violence 2011;5:88-154.

35 Alvarado A, Mónica S. National and internal safety. [In Spanish: Seguridad nacional y seguridad interior]. México: El Colegio de México, 2010:361. 